\title{
A calorimetric study of human $\mathrm{CuZn}$ superoxide dismutase
}

\author{
Costas G. BILIADERIS, ${ }^{*}$ Randall J. WESELAKE, $†$ Abram PETKAU $\ddagger$ and Albert D. FRIESEN§ \\ *Department of Food Science and †Department of Plant Science, University of Manitoba, Winnipeg, Manitoba R3T 2N2, \\ $\ddagger$ Medical Biophysics Branch, Atomic Energy of Canada Ltd. Research Co., Pinawa, Manitoba R0E 1L0, and \\ §Winnipeg Rh Institute Inc., Winnipeg, Manitoba R3T 2N2, Canada
}

\begin{abstract}
Structural alterations, as manifested by thermal transitions, caused by removal or binding of metal ions to human and bovine CuZn superoxide dismutases (SODs) were investigated by differential scanning calorimetry. Although holo forms of the two mammalian enzymes exhibited irreversible thermal transitions $\left(\Delta H_{\text {cal. }}=27.7 \mathrm{~J} / \mathrm{g}\right.$ and $T_{\mathrm{d}}=104^{\circ} \mathrm{C}$ for bovine SOD; $\Delta H_{\text {cal. }}=23.6 \mathrm{~J} / \mathrm{g}$ and $T_{\mathrm{d}}=101{ }^{\circ} \mathrm{C}$ for human SOD), only the bovine apoenzyme showed the presence of a less thermostable structural form $\left(\Delta H_{\text {cal. }}=10.7 \mathrm{~J} / \mathrm{g}\right.$ and $T_{\mathrm{d}}=63^{\circ} \mathrm{C}$ ). These observations suggested that human apo-SOD had considerably less conformational order than bovine apo-SOD. Reconstitution of human and bovine apoenzymes with $\mathrm{Cu}^{2+}$ and $\mathrm{Zn}^{2+}$ resulted in recovery of thermodynamic parameters and specific activity. Binding of $\mathrm{Zn}^{2+}$ alone to human apo-SCD resulted in the formation of two distinct structural units, detectable by differential scanning calorimetry, which underwent conformational disorder at 82 and $101^{\circ} \mathrm{C}$ respectively. Saturation of binding sites with both $\mathrm{Zn}^{2+}$ and $\mathrm{Cu}^{2+}$ appeared to stabilize the enzyme structure further as shown by elimination of the lowtemperature transition and the appearance of another thermal transition at a higher temperature.
\end{abstract}

\section{INTRODUCTION}

Differential scanning calorimetry (d.s.c.) has gained wide acceptance as an analytical tool in biochemical studies of stability, conformational behaviour and interactions of proteins in solution (Donovan, 1984; Biliaderis, 1983). By means of this technique, which provides a direct relation between temperature and heat capacity of the heated specimen, it also is possible to reveal the presence of multiple co-operative units in the molecule that undergo denaturation independently (Privalov, 1979, 1982). Furthermore, calorimetric studies on thermal denaturation of metalloenzymes (Roberts \& Chlebowski, 1984) and other proteins having highaffinity metal-ion-binding sites (Donovan \& Mihalyi, 1985; Eugeseth \& McMillin, 1986) have shown that metal ions stabilize the overall folded protein structure or a particular co-operative block of the molecule.

Superoxide dismutase (SOD) is a metalloenzyme that catalyses the dismutation of the superoxide radical anion $\left(\mathrm{O}_{2}{ }^{-}\right)$into $\mathrm{H}_{2} \mathrm{O}_{2}$ and $\mathrm{O}_{2}$ (McCord \& Fridovich, 1969). CuZn SOD, present in the cytosol of eukaryotic cells, is a dimeric protein, consisting of two similar or identical subunits, with an overall molecular mass of about 32000 $\mathrm{Da}$; each subunit contains one atom each of $\mathrm{Zn}^{2+}$ and $\mathrm{Cu}^{2+}$ (Fridovich, 1974). It appears that $\mathrm{Zn}^{2+}$ has more of a structural role in stabilizing the enzyme while $\mathrm{Cu}^{2+}$ is directly involved in the catalytic cycle (Forman \& Fridovich, 1973; Cass et al., 1977). In a more recent study, Lepock et al. (1985) have used d.s.c. to probe conformational alterations in bovine CuZn SOD, manifested by changes in transition enthalpy and temperature, as consequences of metal ion removal or association. These findings suggested that denaturation of holo and apo forms of the enzyme is irreversible and that both $\mathrm{Cu}^{2+}$ and $\mathrm{Zn}^{2+}$ are important for the organization and stability of the native enzyme structure. In contrast, yeast
CuZn SOD has been reported to undergo reversible thermal denaturation (Arnold \& Lepock, 1982). There have been, however, no studies on the thermal properties of human CuZn SOD with regard to the responses of the enzyme structure to removal or binding of metal ions. Therefore, in the investigation reported herein, d.s.c. was employed to detect changes in structure of human $\mathrm{CuZn}$ SOD with or without bound metal ions. Holo, apo and fully reconstituted apo forms of the bovine enzyme were used for comparative purposes.

\section{EXPERIMENTAL}

\section{SODs}

Human $\mathrm{CuZn}$ SOD was isolated from human erythrocytes by using ion-exchange chromatography followed by metal chelate affinity chromatography on a $\mathrm{Cu}^{2+}$ activated iminodiacetic acid-epoxy-Sepharose 6B gel, and the enzyme was shown to be highly purified on the basis of SDS/polyacrylamide-gel electrophoresis, isoelectric focusing and analytical gel-filtration chromatography (Weselake et al., 1986). Bovine erythrocyte CuZn SOD was obtained from Boehringer-Mannheim (Montreal, Quebec, Canada).

SOD activity was determined by using an end-point assay with a non-enzymic system to generate $\mathrm{O}_{2}{ }^{--}$, essentially as described by Fried (1975), i.e. production of $\mathrm{O}_{2}{ }^{--}$by phenazine methosulphate-catalysed oxidation of $\beta$-NADH was coupled to the reduction of Nitro. Blue Tetrazolium. The final reaction mixture $(3.2 \mathrm{ml})$ consisted of $0.4 \mathrm{~mm}$-Nitro Blue Tetrazolium, $10 \mu \mathrm{M}$-phenäzine methosulphate and $3 \mu \mathrm{M}-\beta$-NADH in $50 \mathrm{~mm}$-potassium phosphate buffer, pH 7.8, containing 0.1 mM-EDTA and $0.3 \mathrm{mg}$ of gelatin $/ \mathrm{ml}$. One unit of SOD inhibited the reduction of Nitro Blue Tetrazolium by $50 \%$. The reagents Nitro Blue Tetrazolium (grade III), phenazine

\footnotetext{
Abbreviations used: SOD, superoxide dismutase; d.s.c., differential scanning calorimetry.
}

* To whom requests for reprints should be addressed. 
Table 1. Specific activity and thermodynamic parameters of various SODs

$T_{\mathrm{d}}$ is the peak temperature of the denaturation endotherm. Abbreviation: sh, shoulder. The $\Delta H$ results represent means \pm S.D. for three replicates.

\begin{tabular}{lccc}
\hline & $\begin{array}{c}\text { Specific } \\
\text { activity } \\
\text { (units/mg) }\end{array}$ & $\begin{array}{c}T_{\mathrm{d}} \\
\left({ }^{\circ} \mathrm{C}\right)\end{array}$ & $\begin{array}{c}\Delta H \\
(\mathrm{~J} / \mathrm{g})\end{array}$ \\
\hline BOD & 590 & $96(\mathrm{sh}), 104$ & $27.5 \pm 1.2$ \\
Bovine holo-SOD & 4 & 63 & $11.8 \pm 1.1$ \\
Bovine apo-SOD apo-SOD $+\mathrm{Cu}^{2+}+\mathrm{Zn}^{2+*}$ & 625 & 94,104 & $26.6 \pm 0.8$ \\
Human holo-SOD & 570 & $92(\mathrm{sh}), 101$ & $23.7 \pm 1.8$ \\
Human apo-SOD & 55 & - & - \\
Human apo-SOD $+\mathrm{Cu}^{2+*}$ & 230 & - & - \\
Human apo-SOD $+\mathrm{Zn}^{2+*}$ & 80 & 82,101 & $18.8 \pm 0.6$ \\
Human apo-SOD $+\mathrm{partial}^{2+} \mathrm{Cu}^{2+}+\mathrm{Zn}^{2+} \dagger$ & 65 & 83,99 & $7.0 \pm 0.7$ \\
Human apo-SOD $+\mathrm{Cu}^{2+}+\mathrm{Zn}^{2+*}$ & 450 & 92,101 & $19.5 \pm 1.3$
\end{tabular}

* Apo forms reconstituted with 2-fold $\mathrm{Cu}^{2+}$ and/or $\mathrm{Zn}^{2+}$ of the stoichiometric amounts of the holoenzyme.

$\dagger$ Apo form reconstituted with $0.8 \mathrm{~mol}$ each of $\mathrm{Cu}^{2+}$ and $\mathrm{Zn}^{2+}$ per mol of protein.

methosulphate and $\beta$-NADH were products of Sigma Chemical Co. (St. Louis, MO, U.S.A.). Protein was determined by the method of Lowry et al. (1951), with bovine serum albumin as a standard.

\section{Preparation of apo-SOD and enzyme reconstitution}

The apo forms of bovine and human SOD were prepared by dialysis (Forman \& Fridovich, 1973; Lepock et al., 1985) against $10 \mathrm{~mm}$-EDTA in $50 \mathrm{~mm}-$ sodium acetate buffer, $\mathrm{pH} 3.67$, in mini-dialysis cells of the type described by Rodriguez \& Tait (1983). Dialysis was carried out at $7{ }^{\circ} \mathrm{C}$ for 2 days with enzyme concentrations of approx. $20 \mathrm{mg} / \mathrm{ml}$. The apoenzymes then were dialysed extensively against $10 \mathrm{~mm}$-ammonium

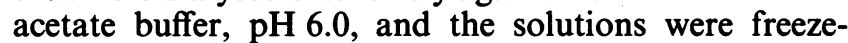
dried.

Reconstitution of the apoenzymes was performed essentially as described by Lepock et al. (1985), with enzyme concentrations between 0.6 and $4.0 \mathrm{~mm}$ prepared in $10 \mathrm{~mm}$-ammonium acetate buffer, $\mathrm{pH}$ 6.0. Bovine apoSOD was reconstituted by addition of 2 -fold $\mathrm{Cu}^{2+}$ and $\mathrm{Zn}^{2+}$ (as $\mathrm{CuSO}_{4}$ and $\mathrm{ZnSO}_{4}$ ) of the stoichiometric amounts required for a fully reconstituted apoenzyme. Reconstitution of human apo-SOD was accomplished by using the following molar ratios of the metal ions to apoenzyme: (a) $4 \mathrm{~mol}$ of $\mathrm{Cu}^{2+} / \mathrm{mol}$; (b) $4 \mathrm{~mol}$ of $\mathrm{Zn}^{2+}$ / mol; (c) $0.8 \mathrm{~mol}$ each of $\mathrm{Cu}^{2+}$ and $\mathrm{Zn}^{2+} / \mathrm{mol} \mathrm{(partial}$ reconstitution); (d) $4 \mathrm{~mol}$ each of $\mathrm{Cu}^{2+}$ and $\mathrm{Zn}^{2+} / \mathrm{mol}$. After the addition of the metal ions, the enzyme solutions were allowed to equilibrate overnight at $7^{\circ} \mathrm{C}$. The reconstituted preparations were dialysed against $0.1 \mathrm{~mm}$ EDTA in $10 \mathrm{~mm}$-ammonium acetate buffer, $\mathrm{pH} 6.0$, for $6 \mathrm{~h}$, and this was followed by extensive dialysis against $150 \mathrm{~mm}-\mathrm{NaCl}$ in $5 \mathrm{~mm}$-sodium phosphate buffer, $\mathrm{pH}$ 7.0. After this dialysis, the enzyme solutions were centrifuged at $12000 \mathrm{~g}$ for $10 \mathrm{~min}$ and the supernatants were used for analysis of specific activity and d.s.c.

D.s.c.

Thermal denaturation was monitored by d.s.c. with a DuPont 9900 Thermal Analyzer equipped with a DuPont 910 cell base and a pressure d.s.c. cell. The thermal analysis system was calibrated with indium
(Biliaderis et al., 1985). A pressure of $1400 \mathrm{kPa}$ with $\mathrm{N}_{2}$ was used for all calorimetric experiments to eliminate pan failure, due to moisture loss, at temperatures above $100^{\circ} \mathrm{C}$. Samples $(8-15 \mu \mathrm{l})$ of enzyme solutions were sealed in DuPont coated hermetic pans and thermal grease, Dow Corning 340 heat-sink compound (DowCorning, Midland, MI, U.S.A.), was used to improve the thermal contact between the pans and the thermocouple detectors. For d.s.c. analyses, solutions of SOD in

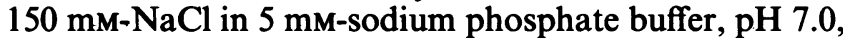
had protein concentrations in the range of about $9-18 \%$. Data were collected at $0.4 \mathrm{~s}$ intervals during the d.s.c. experiments (heating rate $10^{\circ} \mathrm{C} / \mathrm{min}$ ) and stored on floppy discs. Data analysis for denaturation enthalpies $(\Delta H ; \mathrm{J} / \mathrm{g}$ of protein) and peak transition temperatures $\left(T_{\mathrm{d}}\right)$ was performed by using the DuPont software analysis programs. The reproducibility of transition temperatures was generally within $\pm 0.3^{\circ} \mathrm{C}$.

\section{RESULTS AND DISCUSSION}

Before performance of the d.s.c. experiments it was useful to have information on the relative specific activities of holo, apo and metal-ion-reconstituted forms of SOD (Table 1). The apo form of CuZn SOD can be prepared by extensive dialysis of the holoenzyme, at low $\mathrm{pH}$, in the presence of EDTA, and the removal of metal ions from the enzyme is accompanied by loss in enzyme activity (McCord \& Fridovich, 1969; Lepock et al., 1985). After $48 \mathrm{~h}$ of low-pH/EDTA dialysis, the human and bovine apo forms retained about $10 \%$ and $1 \%$ of their original activities respectively. More extensive dialysis of either enzyme beyond $48 \mathrm{~h}$ resulted in apoenzymes of even lower residual activity but with appreciable loss of protein due to precipitation. Bovine apo-SOD fully recovered the initial specific activity of the holoenzyme after treatment with $\mathrm{Cu}^{2+}$ and $\mathrm{Zn}^{2+}$. Human apo-SOD reached about $80 \%$ of the activity of its native counterpart under identical metal ion concentration regimes. Furthermore, treatment of human apoSOD with $\mathrm{Cu}^{2+}$ alone resulted in a preparation having approx. $40 \%$ of the initial activity, whereas in the presence of $\mathrm{Zn}^{2+}$ alone there was no effect on the specific activity. Partial saturation of the metal-ion-binding sites 


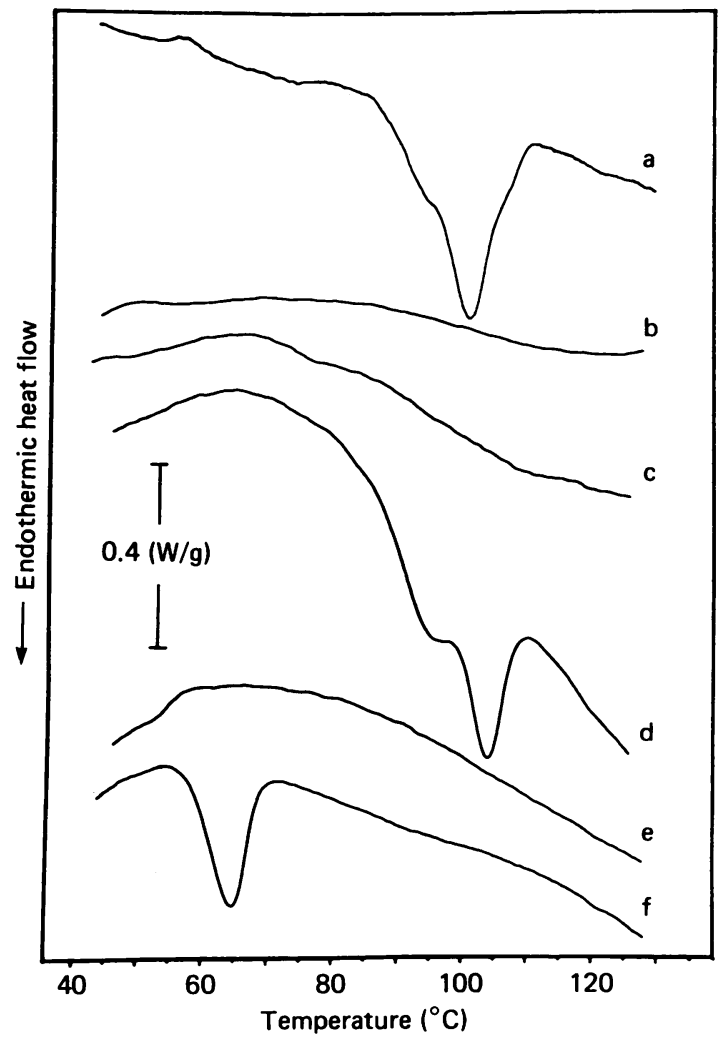

Fig. 1. D.s.c. thermal curves of SODs

The heating rate was $10^{\circ} \mathrm{C} / \mathrm{min}$. Enzymes were prepared in $150 \mathrm{~mm}-\mathrm{NaCl}$ in $5 \mathrm{~mm}$-sodium phosphate buffer, $\mathrm{pH}$ 7.0. Curve a, human holo-SOD, $1.52 \mathrm{mg}$ ( $14.4 \%$ protein); curve $b$, re-scan of a ; curve c, human apo-SOD, $1.62 \mathrm{mg}$ $(13.2 \%)$; curve d, bovine holo-SOD, $1.88 \mathrm{mg}(18.4 \%)$; curve e, re-scan of $d$; curve $f$, bovine apo-SOD, $1.76 \mathrm{mg}$ $(18.0 \%)$

of apo-SOD with the metal ions also showed very little change in activity of the reconstituted system.

Thermal curves derived from d.s.c. experiments are shown in Figs. 1 and 2 . Human and bovine SODs underwent irreversible thermal denaturation (Fig. 1, curves $a, b, d$ and e), since d.s.c. re-scans of previously heated enzyme failed to show any thermal transitions. Earlier work by Forman \& Fridovich (1973) demonstrated that the activity of bovine CuZn SOD was lost irreversibly upon heating enzyme solutions at high temperatures. In contrast, the d.s.c. experiments of Arnold \& Lepock (1982) have shown that yeast $\mathrm{CuZn}$ SOD exhibits partially reversible heat denaturation. The temperatures $\left(T_{\mathrm{d}}\right)$ of the main endothermic transition were 101 and $104^{\circ} \mathrm{C}$ for human and bovine holo-SOD forms respectively (Table 1). Furthermore, the thermal curves of both holoenzymes clearly showed the presence of a d.s.c.-detectable structural component undergoing conformational disorder just before the main 'melting' peak (Fig. 1 , curves a and d); i.e. $T_{d}=92^{\circ} \mathrm{C}$ (human SOD) and $T_{\mathrm{d}}=96^{\circ} \mathrm{C}$ (bovine SOD). Lepock et al. (1985) have made similar observations with regard to bovine $\mathrm{CuZn}$ SOD with the use of d.s.c. Bovine CuZn SOD is considered to be among the most thermostable of globular proteins, including those from extreme thermophiles (Tainer et al., 1982), and the -relatively high denaturation temperatures for the holoenzymes (Fig. 1,

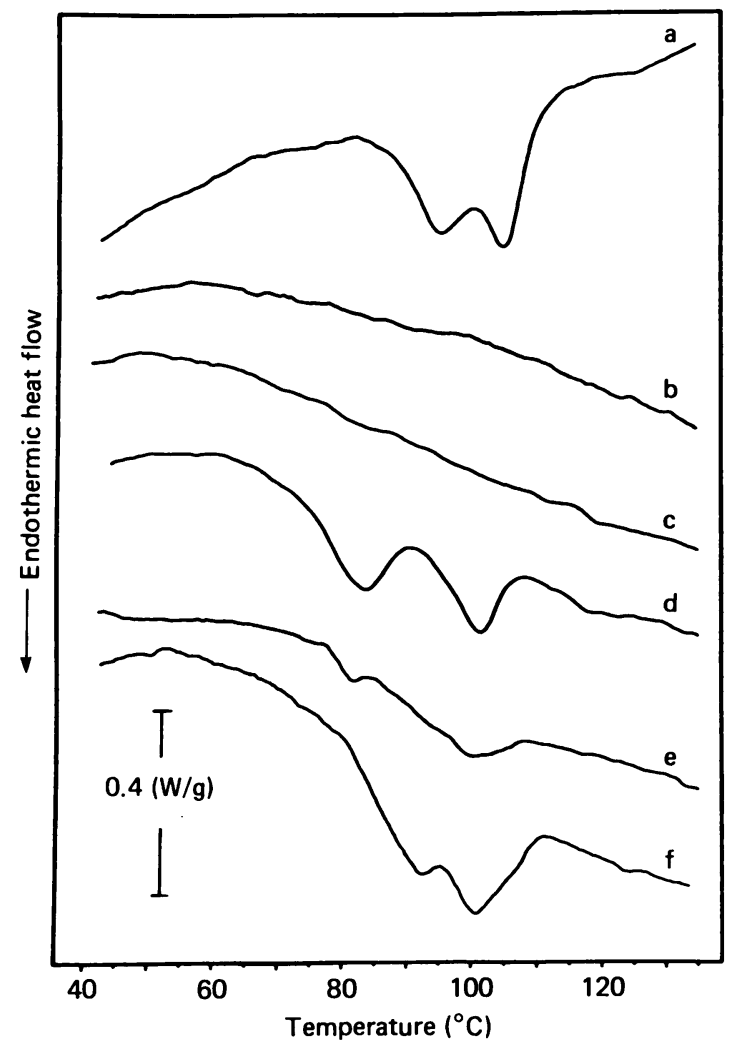

Fig. 2. D.s.c. thermal curves of reconstituted SODs

The heating rate was $10^{\circ} \mathrm{C} / \mathrm{min}$. Enzymes were prepared in $150 \mathrm{~mm}-\mathrm{NaCl}$ in $5 \mathrm{~mm}$-sodium phosphate buffer, $\mathrm{pH}$ 7.0. Curve a, bovine apo-SOD $+\mathrm{Cu}^{2+}+\mathrm{Zn}^{2+}, 1.56 \mathrm{mg}$ $(11.9 \%$ protein); curve $\mathrm{b}$, human apo-SOD, $1.68 \mathrm{mg}$ $(15.4 \%)$; curve c, human apo-SOD $+\mathrm{Cu}^{2+}, 1.23 \mathrm{mg}$ $(9.6 \%)$; curve $\mathrm{d}$, human apo-SOD $+\mathrm{Zn}^{2+}, 1.85 \mathrm{mg}$ $(11.8 \%)$; curve e, human apo-SOD + partial $\mathrm{Cu}^{2+}+\mathrm{Zn}^{2+}$, $1.32 \mathrm{mg}(8.8 \%)$; curve $\mathrm{f}$, human apo-SOD $+\mathrm{Cu}^{2+}+\mathrm{Zn}^{2+}$, $1.25 \mathrm{mg}(9.8 \%)$.

curves a and d) clearly support this contention. The enthalpy values for the holoenzymes (Table 1) most probably reflect not only endothermic contributions (heat of unfolding) but also exothermic effects due to molecular aggregation that can be encountered in heated semi-dilute protein solutions (Privalov, 1979; Biliaderis, 1983).

Human apo-SOD, however, was found to have no d.s.c.-detectable structure as revealed by the lack of any thermal transition within the $20-130^{\circ} \mathrm{C}$ range (Fig. 1, curve c). In contrast, the bovine apoenzyme showed a denaturation endotherm $41^{\circ} \mathrm{C}$ lower (Fig. 1, curve f) than that of its native counterpart (Fig. 1, curve d) with an apparent enthalpy of $11.8 \mathrm{~J} / \mathrm{g}$ (Table 1). These data imply that bovine SOD devoid of $\mathrm{Cu}^{2+}$ and $\mathrm{Zn}^{2+}$ attains a distinct conformational state, as Lepock et al. (1985) have reported. Although bovine and human $\mathrm{CuZn}$ SODs are strongly homologous in their amino acid sequences (Barra et al., 1980; Jabusch et al., 1980), the differences in primary structure that do exist must somehow account for the absence of a d.s.c.-detectable structural unit in human apo-SOD.

The results of metal ion reconstitution experiments are shown in the d.s.c. thermal curves in Fig. 2. Although addition of $\mathrm{Cu}^{2+}$ alone restored approx. $40 \%$ of the 
original activity of the human holoenzyme (Table 1), its presence did not appear to alter the d.s.c.-detectable structure of the apoenzyme (Fig. 2, curve c). In contrast, addition of $\mathrm{Zn}^{2+}$ alone brought about considerable d.s.c.detectable conformational order. The enthalpy of the overall endothermic process was nearly the same as that of fully reconstituted SOD (Table 1). Furthermore, as shown by curve $\mathrm{d}$ in Fig. 2, the calorimetric profile showed the presence of two distinct components. Although there was a high-temperature transition $\left(T_{\mathrm{d}}=\right.$ $101{ }^{\circ} \mathrm{C}$ ), corresponding to the dominant endotherm of the holoenzyme, a second transition at a much lower temperature $\left(T_{\mathrm{d}}=82^{\circ} \mathrm{C}\right)$ also was detected. The thermal profile of the partially reconstituted system (i.e. approximately one-third of the stoichiometric amounts of $\mathrm{Cu}^{2+}$ and $\mathrm{Zn}^{2+}$ were added) also indicated the presence of both transitions. The enthalpy of the overall endothermic process for partially reconstituted human apo-SOD was about one-third of that for the fully reconstituted human enzyme (Table 1). Saturation of binding sites with both metal ions produced further stabilization of the enzyme structure, as shown by disappearance of the lowtemperature transition and the appearance of another transition at a higher temperature $\left(T_{\mathrm{d}}=92^{\circ} \mathrm{C}\right.$; Fig. 1, curve $\mathrm{f}$ ); the second transition remained constant. Fully reconstituted human and bovine apo-SODs, however, did not completely regain the thermal curve profiles of the corresponding holoenzymes. Thus, instead of a shoulder on the low-temperature side of the main endotherm (Fig. 1, curves a and d), a well-defined transition was observed (Fig. 2, curves a and f). The d.s.c. data, however, do imply that $\mathrm{Cu}^{2+}$, in addition to $\mathrm{Zn}^{2+}$, also is involved in recovery and stability of the native enzyme structure. Furthermore, since only the low-temperature component of denaturation appears thermally mobile in its response to metal ion association, it may reflect the thermal disorder of the molecular regions incorporating the ligand-binding sites.

In conclusion, the calorimetric data of $\mathrm{Zn}^{2+}$ - and $\mathrm{Cu}^{2+}+\mathrm{Zn}^{2+}$-reconstituted apo forms of human SOD demonstrated the involvement of both metal ions in the organization of the enzyme molecule. Under the conditions employed in the current study, it appeared that the organizing process was initiated by the binding of $\mathrm{Zn}^{2+}$ to apoprotein. Unlike bovine apo-SOD, however, human apo-SOD did not have any d.s.c.-detectable structure. This finding demonstrates that d.s.c. is an effective way of detecting subtle structural differences between proteins that are otherwise very similar.

This work was supported by a grant from the Natural Sciences and Engineering Research Council of Canada and by ABI Biotechnology, Winnipeg, Manitoba, Canada.

\section{REFERENCES}

Arnold, L. D. \& Lepock, J. R. (1982) FEBS Lett. 146, 302-306

Barra, D., Martini, F., Bannister, J. V., Schinina, M. E., Rotilio, G., Bannister, W. H. \& Bossa, F. (1980) FEBS Lett. 120, 53-56

Biliaderis, C. G. (1983) Food Chem. 10, 239-265

Biliaderis, C. G., Page, C. M., Slade, L. \& Sirrett, R. R. (1985) Carbohydr. Polym. 7, 51-70

Cass, A. E. G., Hill, H. A. O., Smith, B. E., Bannister, J. V. \& Bannister, W. H. (1977) Biochemistry 16, 3061-3066

Donovan, J. W. (1984) Trends Biochem. Sci. 9, 340-344

Donovan, J. W. \& Mihalyi, E. (1985) Biochemistry 24, 3434-3443

Eugeseth, H. R. \& McMillin, D. R. (1986) Biochemistry 25, 2448-2455

Forman, H. J. \& Fridovich, I. (1973) J. Biol. Chem. 248, 2645-2649

Fridovich, I. (1974) Adv. Enzymol. Relat. Areas Mol. Biol. 41, 35-97

Fried, R. (1975) Biochimie 57, 657-660

Jabusch, J. R., Farb, D. L., Kerschensteiner, D. A. \& Deutsch, H. F. (1980) Biochemistry 19, 2310-2315

Lepock, J. R., Arnold, L. D., Torrie, B. H., Andrews, B. \& Kruuv, J. (1985) Arch. Biochem. Biophys. 241, 243-251

Lowry, O. H., Rosebrough, N. J., Farr, A. L. \& Randall, R. J. (1951) J. Biol. Chem. 193, 265-275

McCord, J. M. \& Fridovich, I. (1969) J. Biol. Chem. 244, 6049-6055

Privalov, P. L. (1979) Adv. Protein Chem. 33, 167-241

Privalov, P. L. (1982) Adv. Protein Chem. 35, 1-104

Roberts, C. H. \& Chlebowski, J. F. (1984) J. Biol. Chem. 259, 3625-3632

Rodriguez, R. L. \& Tait, R. C. (1983) Recombinant DNA Techniques: An Introduction, pp. 200-201, Addison-Wesley Publishing. Co., Don Mills

Tainer, J. A., Getzoff, E. D., Beem, K. M., Richardson, J. S. \& Richardson, D. C. (1982) J. Mol. Biol. 160, 181-217

Weselake, R. J., Chesney, S. L., Petkau, A. \& Friesen, A. D. (1986) Anal. Biochem. 155, 193-197 